Scientia Agricola

http://dx.doi.org/10.1590/0103-9016-2015-0058

\title{
Initial horticultural performance of nine 'Persian' lime selections grafted onto Swingle citrumelo
}

Magno Guimarães Santos* , Walter dos Santos Soares Filho, Eduardo Augusto Girardi, Abelmon da Silva Gesteira, Orlando Sampaio Passos, Claudia Fortes Ferreira

Embrapa Cassava and Fruits, R. Embrapa, s/n - 44380-000

- Cruz das Almas, BA - Brazil.

*Corresponding author <magno.santos@embrapa.br>

Edited by: Lincoln Zotarelli

Received February 23, 2015

Accepted September 03, 2015
ABSTRACT: 'Persian' lime (PL) [Citrus latifolia (Yu. Tanaka) Tanaka] is an important species both for domestic fresh fruit consumption in Brazil as well as the export market, since the country is one of the largest producers in the world despite the fact that, in commercial plantations, it is still not uncommon to find trees with low productivity and high plant vigor of unknown origin. Selections of Persian lime 'CNPMF-2000', 'CNPMF-2001', 'CNPMF-01', 'CNPMF-02', 'IAC-5', 'IAC-5.1', 'Bearss', 'Persian-58', and '5059', were therefore grafted onto Swingle citrumelo [C. paradisi Macfad. cv. Duncan $\times$ Poncirus trifoliata (L.) Raf.] rootstocks and evaluated in Cruz das Almas, Bahia, Brazil in a field experiment conducted in a completely randomized block design with five replications and two trees per plot. The biometric attributes (canopy height, diameter and volume), yield parameters (yield during the off-season harvest period, yield per plant, production efficiency), and fruit quality traits, were evaluated. The 'CNPMF-2001', 'CNPMF-01', 'CNPMF-02', 'IAC-5', and 'Bearss' selections had 5-11\% shorter trees than the other cultivars. 'CNPMF-01', 'CNPMF-02', 'Persian-58', and '5059' presented higher yield efficiency values, between 3.1-3.4 $\mathrm{kg} \mathrm{m}^{-3}$, and higher yield levels during the off-season harvest periods. The 'Bearss', 'Persian-58', 'CNPMF-2000', 'AC-5.1' and '5059' selections had more acid fruits and the latter three, smaller fruits. Based on their horticultural performance up to eight years of age, 'CNPMF-01', 'CNPMF-02', 'Persian-58' and '5059' selections were the most promising varieties of Persian lime.

Keywords: Citrus latifolia, rain fed cultivation, scion cultivars

\section{Introduction}

With an annual production of 1.2 million tonnes, Brazil retains approximately $8 \%$ of the world's production of lemons/acid limes and occupies fifth place in world production of these fruits, behind only Mexico, India, China and Argentina (FAO, 2015). In Brazil, cultivation of 'Persian' lime (PL) [Citrus latifolia (Yu. Tanaka) Tanaka] occupies more than 47 thousand hectares with the main producers being the state of São Paulo, with a subtropical climate, followed by the states of Minas Gerais and Bahia, with tropical semiarid climates (IBGE, 2012). In 2011, PL occupied the fourth position when ranking Brazilian exports of fresh fruits with a value in the market surpassed only by mangoes, grapes and melons (FAO, 2015). This crop has also attracted the attention of producers because of the high prices commanded during the off-season of the domestic market.

In Brazil there are only two known PL selections available, 'IAC-5', also known as 'Peruano', and 'Quebra-galho', a local selection contaminated by viroids (Eiras et al., 2010) cultivated, and the most studied, in the southeastern region of the country.

Despite its increasing economic expression, PL cultivation still lacks research that focuses on the diversification of scion and rootstock selections in comparison to the most studied groups of sweet oranges [C. sinensis (L.) Osbeck] and many tangerine varieties.
It is imperative to increase the genetic basis of this species, since new diseases may arise and threaten crop yields. Persian lime selections known as 'CNPMF-2000' 'CNPMF-2001', 'CNPMF-01' and 'CNPMF-02' were obtained through open-pollination. Although it is a triploid species, when PL is cultivated close to other citrus it produces seeds with low frequency (Santos et al., 2013). A number of these selections are being studied in the state of São Paulo, and initial results are promising since there are selections with agronomic characteristics superior to the control, 'IAC-5' (Bremer Neto et al., 2013).

A number of rootstock evaluation studies observed promising horticultural behavior in Swingle citrumelo [C. paradisi Macfad. cv. Duncan $\times$ Poncirus trifoliata (L.) Raf.] in combination with PL (Figueiredo et al., 2002; Espinoza-Nuñez et al., 2011). This rootstock is tolerant to CTV (Citrus tristeza virus) and to $\mathrm{CSDaV}$ (Citrus sudden death associated virus) and has been used in Brazil as rootstock for PL as a substitute for 'Rangpur' lime [C. limonia Osbeck] due to its susceptibility to Phytophthora spp. and CSDaV (Pompeu Junior and Blumer, 2008). Due to the importance of this species for the Brazilian citrus industry and the restricted number of PL selections available, the aim of the present study was to evaluate the initial horticultural performance (performance during the initial growth period up to eight years of age) of nine PL selections grafted onto Swingle citrumelo. 


\section{Materials and Methods}

\section{Location}

The orchard was planted in October 2004 in the municipality of Cruz das Almas, Recôncavo da Bahia, Brazil (1240'39" S, 3906'23" W, $225 \mathrm{~m}$ above sea level).

The climate is classified as Ami according to the Köppen classification. Weather data were obtained from an agrometeorological station. Rain sensor and temperature sensors were at a height of $1.5 \mathrm{~m}$ above the ground. Between 2009 and 2012, the mean annual precipitation was $1065 \mathrm{~mm}$. Climate data referring to the productive period are shown in Figure 1. The period from June to August was characterized as the wet season and from November to March as the dry season. The soil was classified as Typic Haplustox (Soil Survey Staff, 2014) and the experiment was conducted from 2009 to 2012 when fruit production was available.

\section{Plant material and cultural practices}

Nine PL selections (Table 1), grafted onto Swingle citrumelo rootstocks were planted in $5.5 \mathrm{~m} \times 4.0 \mathrm{~m}$ spacing (454 trees per ha) under rain-fed cultivation. The following selections were used: 'CNPMF-2000', 'CNPMF-2001', 'CNPMF-01', 'CNPMF-02', (from Cruz das Almas, Bahia, Brazil), 'IAC-5', 'IAC-5.1' (from Cordeirópolis, São Paulo, Brazil), 'Bearss' and 'Persian-58' (from Riverside, California, USA) and '5059' (of unknown origin). 'IAC-5' was used as a control in this study because it is the main commercial PL selection.

Over the years weed control was conducted using a brush cutter tractor. As to the presence of harmful insects, integrated pest management was considered using insecticides only when populations reached control levels.

There was no directed chemical control to post bloom fruit drop (PFD) caused by Colletotrichum acutatum in the experimental area, since this is a frequent occurrence in commercial orchards in the region studied. Manual pruning of dried branches and suckers was carried out when necessary.

\section{Biometric variables}

Plant height of eight-year-old trees was evaluated at the end of the month of August 2012. The diameter and height of the canopies of the trees were measured using a metric ruler. Height was measured from the soil to the middle section of the top of the plant. The diameter was measured in the direction of the planted row and perpendicular to it for calculating the mean diameter. The canopy volume was calculated by $\mathrm{V}=2 / 3 \pi$ (D) / 2) $2 \mathrm{H}$, whereas, $\mathrm{V}$ is the volume of the canopy in cubic meters, $\mathrm{H}$ is the height of the plant in meters and $\mathrm{D}$ the mean diameter in meters.

\section{Yield variables}

The Yield per plant $(\mathrm{Y})$ is referred to as the total mass $(\mathrm{kg}$ ) of fruits per plant obtained in the years 2009, 2010, 2011 and 2012. Yield between 2004 and 2008 was not computed. The harvest was gathered every year and the values added. The cumulative yield was obtained by adding the yields of the four years evaluated.

Table 1 - Canopy volume, plant height and average canopy diameter of nine selections of eight-year-old 'Persian' lime grafted onto Swingle citrumelo in 2012, Cruz das Almas, BA, Brazil.

\begin{tabular}{|c|c|c|c|}
\hline Selections & Canopy volume & Plant heigh & Canopy diameter \\
\hline & $\mathrm{m}^{3}$ & & \\
\hline CNPMF-2000 & 37.8 & $3.3 \mathrm{a}$ & 4.7 \\
\hline CNPMF-2001 & 36.5 & $3.1 \mathrm{~b}$ & 4.8 \\
\hline CNPMF-01 & 35.9 & $3.1 \mathrm{~b}$ & 4.8 \\
\hline CNPMF-02 & 36.3 & $3.0 \mathrm{~b}$ & 4.8 \\
\hline IAC-5 & 40.9 & $3.1 \mathrm{~b}$ & 4.9 \\
\hline IAC-5.1 & 40.9 & $3.4 \mathrm{a}$ & 4.8 \\
\hline BEARSS & 37.0 & $3.1 \mathrm{~b}$ & 4.8 \\
\hline 5059 & 38.7 & $3.3 \mathrm{a}$ & 4.8 \\
\hline PERSIAN-58 & 44.2 & $3.4 \mathrm{a}$ & 4.9 \\
\hline F Test & $0.18^{\text {ns }}$ & 0.00 ** & $0.45^{\text {ns }}$ \\
\hline CV (\%) & 13 & 6 & 5 \\
\hline
\end{tabular}

Average values within columns followed by the same letter belong to the same group, according to the Scott-Knott test $(p<0.05)$. CV - Coefficient of variation; " nsnon-significant; * ${ }^{*}$ significant at $p<0.01$.

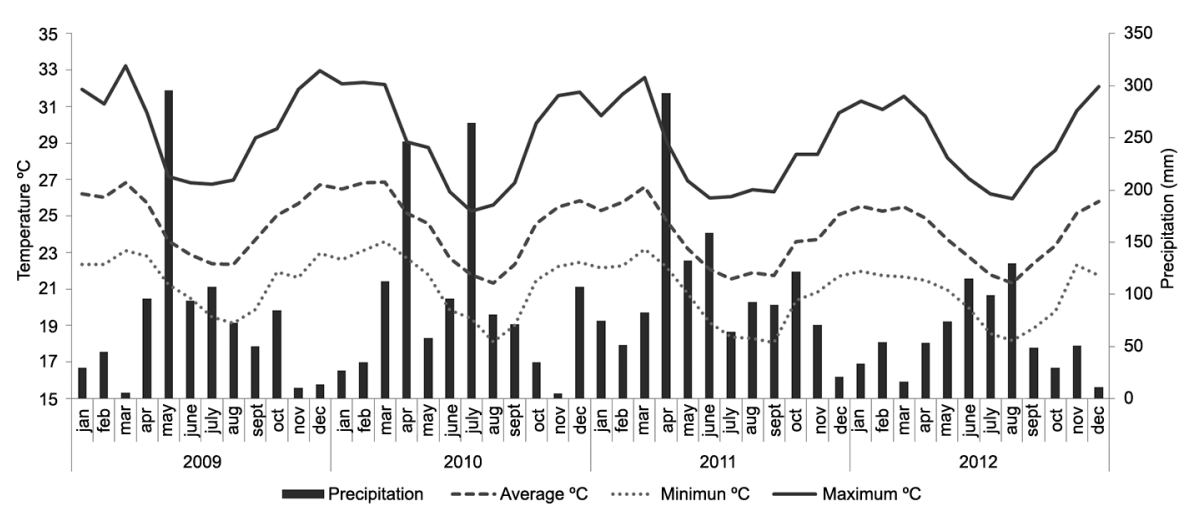

Figure 1 - Rainfall and average, minimum and maximum air temperatures between Jan 2008 and Dec 2012, Cruz das Almas, BA, Brazil. Source: Meteorological Station at Embrapa Cassava and Tropical Fruits 
The yield efficiency of fruits (YE) was calculated by $\mathrm{YE}=\mathrm{Y} / \mathrm{V}\left(\mathrm{kg} \mathrm{m}^{-3}\right)$ in the years 2010, 2011 and 2012 .

The fruit percentage produced during the off-season's harvest periods (OSH) in 2012 was calculated by $\mathrm{OSH}$ = YSS / Y100, where 'YSS' is the fruit yield per plant during the second semester of 2012 divided by the total yield of fruits per plant in 2012. Two harvests were gathered during the first semester, in March and July, and two more during the second semester, in September and November.

\section{Variables of fruit quality}

A sample of 10 fruits was collected from each plot, randomly chosen surrounding the canopy of two trees, with green coloration of $\mathrm{C} 1$ to $\mathrm{C} 3$, ranging from dark green with rough peel to a light green, according to the PL classification scale (CEAGESP, 2011). The following physicochemical attributes were evaluated: a) fruit length and diameter, measured with a metric ruler $(\mathrm{cm})$; b) fruit mass (g), measured using a digital scale; c) juice yield, whose evaluation was based on the ratio between juice weight and fruit weight and expressed as a percentage $(\%)$; $)$ peel thickness, measured with a caliper $(\mathrm{mm})$; e) soluble solid concentration (SS), measured using a direct reading refractometer and expressed as a percentage by weight ( ${ }^{\circ}$ Brix); f) titratable acidity (TA), measured by diluting approximately $0.5 \mathrm{~g}$ of juice (from each sample) in $40 \mathrm{~mL}$ distilled water using a digital burette. Titration of the solution with $\mathrm{NaOH}$ at $0.1 \mathrm{~N}$, expressed as a percentage, was carried out, and a ratio calculated by SS/AT. Results of all the variables of fruit quality are presented in terms of averages from 2009 to 2012 .

\section{Statistical analysis}

The experimental design was completely randomized blocks with nine treatments (PL selections), five replications and two trees in the unit. Data was submitted to the analysis of variance and the means were grouped by the Scott-Knott test $(p<0.05)$.

\section{Results and Discussion}

\section{Biometric}

No significant differences were observed for any of the measured plant development variables in 2012 between the evaluated PL selections, with the exception of plant height (Table 1). Two groups were formed for plant height: the first one by 'CNPMF-02', 'CNPMF-01', 'CNPMF-2001', 'Bearss' and 'IAC-5', with height between 3.0 and $3.1 \mathrm{~m}$, and the second group, between 3.3 and $3.4 \mathrm{~m}$. Canopy volume ranged between 35.9 and $44.2 \mathrm{~m}^{3}$ for all selections, whereas the average diameter of canopy was $4.8 \mathrm{~m}$.

The selections 'CNPMF-2000', 'CNPMF-2001', 'IAC-5', 'IAC-5.1' and 'CNPMF / EECB' (derived from 'CNPMF-01') grafted onto six year old Swingle citrumelo, were evaluated in Bebedouro, SP, Brazil. 'IAC-5' presented small height and canopy volume and the others presented similar plant growth (Bremer Neto et al., 2013).
In addition, 'CNPMF-01' PL trees grafted onto 'Cleopatra' mandarin (C. reshni Hort. ex Tan.) after nine years, were $4.5 \mathrm{~m}$ in height (Stuchi et al., 2002). In the same region, ten-year-old 'IAC-5' PL trees grafted onto Swingle citrumelo presented canopies of $3.9 \mathrm{~m}$ height and $5.9 \mathrm{~m}$ diameter (Figueiredo et al., 2002). In another experiment on six-year old trees this same combination showed higher mean height than that observed in the present study (Espinoza-Núñez et al., 2011).

In the Grande Jaguey Region, in Cuba, 'Persian-58' PL trees were inoculated with the citrus exocortis viroid CEVd, which reduced the size of trees by $23 \%$, thereby increasing productive efficiency from 1.5 to $2.6 \mathrm{~kg} \mathrm{~m}^{-3}$ in comparison to the control (Pérez et al., 2004). The Flying Dragon trifoliate orange $[P$. trifoliata (L.) Raf. var. monstrosa T. Ito] has induced significant reductions in height when used as rootstock for the 'IAC-5.1' PL (CantuariasAvilés et al., 2012) and 'IAC-5' (Espinoza-Núñez et al., 2011) in comparison to Swingle citrumelo. In the South Pacific island of New Caledonia, Flying Dragon trifoliate orange grafted with PL promoted a five-fold increase in the tree density of the plantation and an increase of 3.3 times more productivity per hectare in comparison to PL grafted onto vigorous rootstocks (Mademba-Sy et al., 2012). Selections of PL smaller in height than some of those observed in this study (Table 1) could further enhance this reduction effect in the canopy of rootstocks. The importance of selections with smaller canopies is associated especially with harvesting feasibility, since very high trees hinder manual harvest and make necessary the use of tools such as hooks for PL fruit picking. This type of procedure may lead to fruit and plant injuries which reduced the efficiency of the treatments applied during the post-harvest stage (Bassan et al., 2013).

\section{Yield}

Throughout the evaluation period, the PL selections were significantly different for all the yield variables studied (Table 2).

With regard to fruit yield per plant, in 2009, 'CNPMF-02', '5059' and 'Persian-58' were the most productive. In 2010, 'CNPMF-2000' and 'CNPMF-2001' resulted in lower yield in comparison with the remaining selections, whereas in 2011, '5059' and 'Persian-58', maintained a higher yield per plant. 'Persian-58' was the most productive selection in 2012 (152 kg per plant). Considering the cumulative yield in 2009 to 2012, 'Persian-58' was also the most productive selection with $322.4 \mathrm{~kg}$ per plant and 'CNPMF - 2000', 'CNPMF 2001' and 'IAC 5' the least productive, with 28.0, 44.2 and $39.9 \mathrm{~kg}$ per plant, respectively.

In terms of yield efficiency, selections 'Persian-58' and ' 5059 ' showed better performance in the years of 2010 and 2011. In 2012, these same selections, along with 'CNPMF-01' and 'CNPMF-02', presented greater efficiency, namely, between 3.1 to $3.4 \mathrm{~kg} \mathrm{~m}^{-3}$. In general, selections 'CNPMF-2000', 'CNPMF-2001' and 'IAC-5' presented the lowest means for all the yield variables. 
Table 2 - Yield per plant, yield efficiency and yield during the off-season harvest period (OSH) of nine 'Persian' lime selections grafted onto Swingle citrumelo in the period 2009-2012, Cruz das Almas, BA, Brazil.

\begin{tabular}{|c|c|c|c|c|c|c|c|c|c|}
\hline \multirow{2}{*}{ Cultivars } & \multicolumn{5}{|c|}{ Yield (kg per plant) } & \multicolumn{3}{|c|}{ Yield efficiency $\left(\mathrm{kg} \mathrm{m}^{-3}\right)$} & \multirow{2}{*}{$\begin{array}{c}\text { OSH (\%) } \\
2012\end{array}$} \\
\hline & 2009 & 2010 & 2011 & 2012 & Cumulative $^{1}$ & 2010 & 2011 & 2012 & \\
\hline CNPMF-2000 & $1.5 \mathrm{~b}$ & $8.7 \mathrm{~b}$ & $6.5 d$ & $28.0 \mathrm{~d}$ & $44.7 \mathrm{e}$ & $0.7 \mathrm{~b}$ & $0.3 d$ & $0.7 \mathrm{c}$ & $17 c$ \\
\hline CNPMF-2001 & $2.6 \mathrm{~b}$ & $3.5 \mathrm{~b}$ & $11.5 \mathrm{~d}$ & $44.2 \mathrm{~d}$ & $61.8 \mathrm{e}$ & $0.2 \mathrm{~b}$ & $0.4 \mathrm{~d}$ & $1.2 \mathrm{c}$ & $37 \mathrm{~b}$ \\
\hline CNPMF-01 & $6.1 \mathrm{~b}$ & $27.1 \mathrm{a}$ & $54.9 c$ & $120.5 \mathrm{~b}$ & 208.6 c & $1.6 \mathrm{a}$ & $1.9 \mathrm{c}$ & $3.4 \mathrm{a}$ & $55 a$ \\
\hline CNPMF-02 & $9.1 \mathrm{a}$ & $22.5 \mathrm{a}$ & $71.7 \mathrm{~b}$ & $114.8 b$ & $218.2 \mathrm{c}$ & $1.4 \mathrm{a}$ & $2.7 \mathrm{~b}$ & $3.2 \mathrm{a}$ & $48 \mathrm{a}$ \\
\hline IAC-5 & $3.8 b$ & $17.7 \mathrm{a}$ & $17.2 \mathrm{~d}$ & $39.9 \mathrm{~d}$ & $78.6 \mathrm{e}$ & $0.9 b$ & $0.6 d$ & $1.0 \mathrm{c}$ & $34 \mathrm{~b}$ \\
\hline IAC-5.1 & $5.6 \mathrm{~b}$ & $19.5 \mathrm{a}$ & $41.8 \mathrm{c}$ & $61.1 \mathrm{c}$ & $127.9 \mathrm{~d}$ & $1.0 \mathrm{~b}$ & $1.5 \mathrm{c}$ & $1.5 \mathrm{c}$ & $29 \mathrm{~b}$ \\
\hline BEARSS & $4.5 \mathrm{~b}$ & $24.2 \mathrm{a}$ & $53.9 \mathrm{c}$ & $83.4 \mathrm{c}$ & $165.9 d$ & $1.6 \mathrm{a}$ & $2.0 \mathrm{~b}$ & $2.3 \mathrm{~b}$ & $39 b$ \\
\hline 5059 & $14.6 \mathrm{a}$ & $32.6 \mathrm{a}$ & $99.0 \mathrm{a}$ & $120.1 b$ & $266.3 b$ & $2.0 \mathrm{a}$ & $3.3 \mathrm{a}$ & $3.1 \mathrm{a}$ & $50 \mathrm{a}$ \\
\hline PERSIAN-58 & $14.6 \mathrm{a}$ & $37.7 \mathrm{a}$ & $118.2 \mathrm{a}$ & 151.9 a & $322.4 \mathrm{a}$ & $1.9 \mathrm{a}$ & $3.6 \mathrm{a}$ & $3.4 \mathrm{a}$ & $51 \mathrm{a}$ \\
\hline F Test & $0.00^{* *}$ & $0.00^{* *}$ & $0.00^{* *}$ & $0.00^{* *}$ & $0.00^{* *}$ & $0.00^{* *}$ & $0.00^{* *}$ & $0.00^{* *}$ & $0.00^{* *}$ \\
\hline CV (\%) & 66 & 58 & 32 & 24 & 23 & 47 & 32 & 24 & 30 \\
\hline
\end{tabular}

Average values within columns followed by the same letter belong to the same group, according to the Scott-Knott test ( $p<0.05)$. CV - Coefficient of variation;

** significant at $p<0.01 .{ }^{1}$ Average cumulative yield per plant over the four years evaluated (kg per plant).

In Bebedouro, the selection 'CNPMF / EECB' obtained higher yield efficiency $\left(2.8 \mathrm{~kg} \mathrm{~m}^{-3}\right)$ in comparison to 'IAC-5' and 'IAC-5.1', which showed intermediate efficiency, and that of 'CNPMF-2000' and 'CNPMF-2001', which showed lower efficiency (Bremer Neto et al., 2013).

In the present study, the production variables were responsible for the main differences between PL selections (Table 2). Yield per plant, from the sixth to the seventh year of age, increased more than $100 \%$ for most selections, except in the case of 'CNPMF-2000' and 'IAC-5'. For the seventh to the eighth year, the highlight was selection 'CNPMF-01' which again registered an increase of more than $100 \%$ in yield and entered the group of selections with the highest yield efficiency. In another study, 'CNPMF-01' trees presented their highest increase in yield from the second to the third year, increasing from 5 to $90 \mathrm{~kg}$ per plant, whereas in the eighth year of age, trees produced $136 \mathrm{~kg}$ per plant (Stuchi et al., 2002). Considering the yield efficiency at six years of age, the results for 'IAC-5' and 'IAC 5.1' PL on Swingle citrumelo in Cruz das Almas, Bahia, were inferior to the trees from these same combinations in Bebedouro, São Paulo, whereas the first produced $3.4 \mathrm{~kg} \mathrm{~m}^{-3}$ (Espinoza-Núñez et al., 2011) and the second $1.3 \mathrm{~kg} \mathrm{~m}^{-3}$ (Cantuarias-Avilés et al., 2012). The selections 'CNPMF-01', 'CNPMF-02', 'Persian-58' and '5059' presented higher fruit yield in the months of September and November, approximately $50 \%$ of the annual total (Table 2). Thus, they are good options for the internal market in Brazil, since the off-season harvest period of PL occurs in this same period and there are substantial differences in the price of PL between the harvest and off-season harvest periods in the Brazilian market. Furthermore, in 2011 Brazil exported less than $6 \%$ of its production, meaning that the internal market is the main destination of production (FAO, 2015).

There was no chemical control PFD in the experimental area in an attempt to reproduce the usual management of the study region since small producers do not perform this practice. However, occasionally, there were symptoms of the disease during the evaluation period, between the evaluated selections.

\section{Fruit quality}

There were differences in fruit mass, peel thickness, ratio and titratable acidity between the PL selections (Table 3).

Two groups were identified in regard to fruit mass. The first group ('CNPMF-2001', 'CNPMF-01', 'CNPMF-02', 'IAC-5', 'Bearss' and 'Persian-58') presented fruits in the 105.7 to $115.7 \mathrm{~g}$ range, whereas the second group ('CNPMF-2000', 'IAC-5.1' and '5059'), between 91.2 and $96 \mathrm{~g}$. Fruit length was between 5.7 and $6.4 \mathrm{~cm}$ and diameter between 5.4 and $5.7 \mathrm{~cm}$, regardless of the selection. Selections 'CNPMF-2000' and 'CNPMF-2001' had fruits with thicker peel in comparison to the remaining ones. Juice content was between 36 $\%$ and $44 \%$ for all selections evaluated.

\section{Selections 'CNPMF-2001', 'CNPMF-01',} 'CNPMF-02' and 'IAC-5' produced fruits with lower acidity in comparison to the remaining selections, but did not differ between each other. Soluble solid content comprised between 7.3 and $7.7^{\circ}$ Brix, whereas 'CNPMF-2001' presented higher ratios in all selections (Table 3).

The internal Brazilian market prefers PL juicy fruits with smooth peel whereas the external market prefers fruits with intense green peel. In general, fruits from all the selections evaluated in this work had attributes considered adequate for both the internal and the external markets (Table 3).

Regarding fruit dimensions, the data presented in this study were superior to those reported by Figueiredo et al., (2002) for 'IAC-5' and similar to those reported by Stuchi et al., (2009) for 'IAC-5.1'. In Bebedouro, São Paulo, fruits with 'IAC-5' canopy over many rootstocks did not differ in terms of mass, length and fruit diameter (Figueiredo et al., 2002). In contrast, 'IAC-5.1' fruits in combination with eleven rootstocks presented differenc- 
Table 3 - Weight (FW), length (FL), diameter (FD), peel thickness (PT), juice yield (JY), titratable acidity (TA), soluble solids (SS), and ratio (RT) of fruits from nine selections of 'Persian' lime grafted onto Swingle citrumelo in the period 2009-2012, Cruz das Almas, BA, Brazil.

\begin{tabular}{|c|c|c|c|c|c|c|c|c|}
\hline Cultivars & FW & $\mathrm{FL}$ & FD & PT & $J Y$ & TA & $\mathrm{SS}^{1}$ & RT \\
\hline & g & 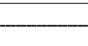 & 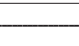 & $\mathrm{mm}$ & 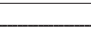 & 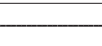 & & \\
\hline CNPMF-2000 & $91.2 \mathrm{~b}$ & 5.7 & 5.4 & $3.7 b$ & 42 & $6.6 \mathrm{a}$ & 7.7 & $1.2 \mathrm{a}$ \\
\hline CNPMF-2001 & $115.7 \mathrm{a}$ & 6.4 & 5.7 & $4.4 \mathrm{~b}$ & 36 & $6.2 \mathrm{~b}$ & 7.7 & $1.3 \mathrm{~b}$ \\
\hline CNPMF-01 & $108.2 \mathrm{a}$ & 6.3 & 5.7 & $3.3 \mathrm{a}$ & 38 & $6.5 b$ & 7.6 & $1.2 \mathrm{a}$ \\
\hline CNPMF-02 & $106.0 \mathrm{a}$ & 6.0 & 5.5 & $3.3 \mathrm{a}$ & 37 & $6.5 b$ & 7.3 & $1.1 \mathrm{a}$ \\
\hline IAC-5 & $108.6 \mathrm{a}$ & 6.2 & 5.7 & $3.1 \mathrm{a}$ & 38 & $6.3 b$ & 7.3 & $1.2 \mathrm{a}$ \\
\hline IAC-51 & $92.4 \mathrm{~b}$ & 5.8 & 5.6 & $3.5 \mathrm{a}$ & 39 & $6.8 \mathrm{a}$ & 7.7 & $1.1 \mathrm{a}$ \\
\hline BEARSS & $107.6 \mathrm{a}$ & 6.2 & 5.6 & $3.2 \mathrm{a}$ & 38 & $6.9 a$ & 7.6 & $1.1 \mathrm{a}$ \\
\hline 5059 & $96.0 \mathrm{~b}$ & 6.3 & 5.7 & $3.2 \mathrm{a}$ & 44 & $6.9 a$ & 7.4 & $1.1 \mathrm{a}$ \\
\hline PERSIAN-58 & $105.7 \mathrm{a}$ & 6.4 & 5.6 & $3.0 \mathrm{a}$ & 39 & $6.6 \mathrm{a}$ & 7.4 & $1.1 \mathrm{a}$ \\
\hline F Test & 0.00 ** & $0.11^{\text {ns }}$ & $0.89^{\text {ns }}$ & $0.01^{* *}$ & $0.16^{\text {ns }}$ & 0.01 ** & $0.21^{\text {ns }}$ & 0.01 * * \\
\hline CV \% & 9 & 5.6 & 5.5 & 13 & 11 & 4 & 4 & 4 \\
\hline
\end{tabular}

Average values within columns followed by the same letter belong to the same group, according to the Scott-Knott test $(p<0.05)$. CV - Coefficient of variation;

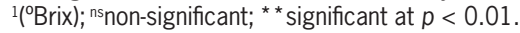

es for the following attributes: soluble solids, ratio, peel thickness, percentage of juice and fruit mass (Stuchi et al., 2009).

In Maringá, in the state of Paraná, Brazil, different rootstocks did not influence fruit mass and ratio, but did influence juice percentage, soluble solids and acidity of 'IAC-5' PL fruits (Stenzel and Neves, 2004).

Fruits from the PL selections analyzed in this study presented a lower concentration of soluble solids when compared to results from other works (Bremer Neto et al., 2013; Cantuarias-Avilés et al., 2012), which may be explained by the rainfall at the time of harvest (Figure 1), which possibly influences the concentration of soluble solids in the fruits. Nonetheless, in general, fruit quality attributes were insufficient for differentiating the selections studied, whose fruits seemed to be very similar, and most differences observed were in relation to the production of fruit per plant.

The period of evaluation in this work corresponded to the initial phase of fruit production for PL, characterized by the annual increment until reaching productive stability that occurs around the eighth year of age of the crop (Stuchi et al., 2002).

Although in this experiment the initial performance of 'CNPMF-01', 'CNPMF-02', 'Persian-58' and '5059' was considered superior than the commercial selection currently in use in Brazil ('IAC-5') a longer evaluation period is required before making a final recommendation.

\section{Conclusions}

The 'Persian' lime selections 'Persian-58', '5059', 'CNPMF-01' and 'CNPMF-02' presented higher productive efficiency, higher accumulated production and higher production of fruits in the off-season harvest up to the eighth year of age, showing promise for cultivation in tropical climates. Fruit quality of these selections were similar to that for the commercial selections 'IAC5 ' and 'IAC-5.1'.

\section{Acknowledgments}

The authors thank Embrapa Cassava and Tropical Fruits for the financial support of the project, also the Federal University of Bahia Reconcavo for the Graduate study (Master's Degree).

\section{References}

Bassan, M.M.; Mourão Filho, F.A.A.; Caron, V.C.; Couto, H.T.Z.; Jacomino, A.P. 2013. The harvesting system affects the quality and conservation of the 'Tahiti- acid lime. Scientia Horticulturae 155: 72-77.

Bremer Neto, H.; Mourão Filho, F.A.A.; Stuchi, E.S.; EspinozaNúñez, E.; Cantuarias-Avilés, T. 2013. The horticultural performance of five 'Tahiti' lime selections grafted onto 'Swingle' citrumelo under irrigated and non-irrigated conditions. Scientia Horticulturae 150: 181-186.

Cantuarias-Avilés, T.; Mourão Filho, F.A.A.; Stuchi, E.S.; Silva, S.R.; Espinoza-Núñez, E.; Bremer Neto, H. 2012. Rootstocks for high fruit yield and quality of 'Tahiti' lime under rain-fed conditions. Scientia Horticulturae 142: 105111.

Companhia de Entrepostos e Armazéns Gerais de São Paulo [CEAGESP]. 2011. Citrus classification standards $=$ Normas de classificação: citros de mesa. Available at: http://www. hortibrasil.org.br/jnw/images/stories/folders/citros.pdf [Accessed Dec 4, 2014] (in Portuguese).

Eiras, M.; Silva, S.R.; Stuchi, E.S.; Flores, R.; Daros, J.A. 2010. Viroid species associated with the bark-cracking phenotype of 'Tahiti' acid lime in the State of São Paulo, Brazil. Tropical Plant Pathology 35: 303-309.

Espinoza-Nuñez, E.; Mourão Filho, F.A.A.; Stuchi, E.S.; Cantuarias-Avilés,T.; Dias, C.T.S. 2011. Performance of 'Tahiti' acid lime on twelve rootstocks under irrigated and non-irrigated conditions. Scientia Horticulturae 129: 227-231.

Food and Agriculture Organization [FAO]. 2015. Agricultural production index. Available at: http://faostat.fao.org [Accessed Jan 23, 2015] 
Figueiredo, J.O.; Stuchi, E.S.; Donadio, L.C.; Teófilo Sobrinho, J.; Laranjeira, F.F.; Pio, R.M.; Sempionato, O.R. 2002. Rootstocks for Persian lime in the Bebedouro region, São Paulo State. Revista Brasileira de Fruticultura 24: 155-159 (in Portuguese, with abstract in English).

Instituto Brasileiro de Geografia e Estatística [IBGE]. 2012. Municipal Agricultural Production = Produção Agrícola Municipal. Available at: http://www.ibge.gov.br [Accessed Oct 12, 2014] (in Portuguese).

Mademba-Sy, F.; Lemerre-Desprez, Z.; Lebegin, S. 2012. Use of flying dragon trifoliate orange as dwarfing rootstock for citrus under tropical climatic conditions. Hortscience 47: 11-17.

Pérez, R.; García, M.E.; Del Valle, N.; Correa, E.; Rodríguez, D.; Velázquez, K.; Pérez, J.M. 2004. Effects of viroid inoculation on 'Sra-58 Persian' lime trees (Citrus latifolia Tan.) grafted on Citrus macrophylla west. under Cuban conditions. i: promotion stage. Acta Horticulturae (ISHS) 632: 295-299.

Pompeu Junior, J.; Blumer, S. 2008. Citrus sudden death: susceptibility of rangpur lime selections and the use of interstocks. Revista Brasileira de Fruticultura 30: 371-378 (in Portuguese, with abstract in English).
Santos, M.G.; Passos, O.S.; Soares Filho, W.S.; Girardi, E.A. Gesteira, A.S.; Ferreira, C.F. 2013. Variability analysis of 'Persian' acid lime tree selections using agronomic and molecular markers. Genetics and Molecular Research 12: 4604-4614.

Soil Survey Staff. 2014. Keys to Soil Taxonomy, 12ed. USDANRCS, Washington, DC, USA.

Stenzel, N.M.C.; Neves, C.S.V. 2004. Rootstocks for 'Tahiti' lime. Scientia Agricola 61: 151-155.

Stuchi, E.S.; Donadio, L.C.; Sempionato, O.R. 2002. Yield and tree size of a Tristeza cross-protected Persian lime clone in the Bebedouro region, State of São Paulo, Brazil. Laranja 23: 221230 (in Portuguese, with abstract in English).

Stuchi, E.S.; Martins, A.B.G.; Lemo, R.R.; Cantuaria-Avilés, T. 2009. Fruit quality of 'Tahiti' lime (Citrus latifolia Tanaka) grafted on twelve different rootstocks. Revista Brasileira de Fruticultura 31: 454-460. 